九州大学学術情報リポジトリ

Kyushu University Institutional Repository

\title{
A Study of Marketing Information and Communication for Fresh Vegetable in Thai land
}

\section{Treewannakul, Panamas}

Laboratory of Food Marketing, Division of Industrial Organization of Agribusiness, Department of Agricultural \& Resource Economics, Graduate School of Bioresource and Bioenvironmental Sciences, Kyushu University

Fukuda, Susumu

Laboratory of Agricultural Marketing, Department of Agricultural Economics and Management, Faculty of Agriculture, Kagoshima University

https://doi.org/10.5109/17817

出版情報：九州大学大学院農学研究院紀要. 55 (1)，pp.153-158，2010-02-26. Faculty of Agriculture, Kyushu University

バージョン：

権利関係 : 


\title{
A Study of Marketing Information and Communication for Fresh Vegetable in Thailand
}

\section{Panamas TREEWANNAKUL ${ }^{1}$ and Susumu FUKUDA*}

Laboratory of Agricultural Marketing, Division of Industrial Organization of Agribusiness, Department of Agricultural and Resource Economics, Faculty of Agriculture, Kyushu University, Fukuoka 812-8581, Japan

(Received October 15, 2009 and accepted November 19, 2009)

\begin{abstract}
This study is dealt with the marketing information in role and provision in marketing information service. Including, identify marketing information needs for fresh vegetable market which brings about development of fresh vegetable marketing information and communication in Thailand. The results were as follows.

1) The role of marketing information for vegetables in Thailand was designed to: (1)provide local producers and traders information on wholesale and retail prices of vegetable on a regular basis; (2)provide producers information on annual price trends of farm commodities for better production scheduling; (3)assist producers in deciding where, when, how much, to whom and in what price to sell their current produce in order to lessen marketing risk; (4improve the bargaining position of producers; and (5)help institutional buyer keep updated prices as bases for their procurements.

2) Vegetable marketing information is provided by Department of Internal Trade and Office of Agricultural Economics. They collects weekly and monthly data which are farm gate price and average market price and distributes them to market members. They will then provide price information to producers, traders, and consumers as a major service item. Reports are issued on a daily, weekly, monthly, and annual basis. The marketing information flash through the communication techniques by extension workers from Agricultural Extension Office, and main public media releases such as radio, television, and newspaper, as well as through government printed reports.

3) The marketing information needs of various stakeholders consist of: (1information on markets according to season and area; (2)quality demands, efficient production, storage, processing methods; (3)prices along the chain; (4)Lists of buyers; (5)market regulations and policies; (6)meetings and workshops; (7)size and location of sources of raw materials
\end{abstract}

\section{INTRODUCTION}

The function of marketing information for vegetable production is to answer the basic questions asked by farmers: What should I produce? When and where should I sell? and for what price? The major problem, however, have been shown that most Thai vegetable producers make little use of marketing information services. Instead, they are dependent on other neighboring farmers and middlemen as main source of marketing information.

Farmers with information can decide whether or not to harvest, so to avoid sending produce to market in times of glut. Accurate and timely information should reduce the costs of food marketing. However, information cannot be perfect. Firstly, prices move too rapidly for available information to serve as more than a guide to likely returns. Secondly, the costs of improving information have to be offset by the additional benefits. Even when more precise information can be obtained, it might be too costly to obtain. This implies that those involved in marketing will always have to take decisions based on varying degrees of imperfect information.

${ }^{1}$ Laboratory of Food Marketing, Division of Industrial Organization of Agribusiness, Department of Agricultural \& Resource Economics, Graduate School of Bioresource and Bioenvironmental Sciences, Kyushu University

* Laboratory of Agricultural Marketing, Department of Agricultural Economics and Management, Faculty of Agriculture, Kagoshima University, Kagoshima

* Corresponding author (E-mail: sufukuda@agr.kyushu-u.ac.jp)
Lack of market information is a key bottleneck for agricultural development. It remains difficult to link farmers to markets if farmers lack information on prices, quality requirements and markets. Such system often relies on combined efforts of various stakeholders: primary producers, traders, government. Thus, before designing marketing information needs that may impact on specific communities, a survey is needed to be undertaken. The use of focus group by participatory approach on stakeholder can prove the hypothesis that marketing networks reflect varied and complex social and economic interrelationships in term of marketing information need. Participatory research is the specific technique which is used to encourage greater involvement among people and to enable them to take the leading role in appraising conditions and identifying solutions. It allows local people to present their own priorities for development and get them incorporated into development plans

The purpose of this paper is to describe the performance of marketing information in role, in provision and constraint of marketing information. Including, share experiences by participation approach among stakeholders in vegetable market and identify problem issues, market information needs, and expected benefits from improving marketing information in vegetable market which bring about development of fresh vegetable marketing information and communication system in Thailand. 


\section{MATERALS AND METHODS}

The study was conducted through focused and open discussion for finding the role, provision, and constraint of marketing information with 3 representatives from Department of Internal Trade (DIT) under the Ministry of Commerce, Office of Agricultural Economics (OAE) and Department of Agricultural Extension (DOAE) under the Ministry of Agriculture and Cooperatives, and with 6 sellers and 12 purchasers from 6 wholesale markets in Bangkok in September 2007.

Including opened discussion workshop which was organized in August 2008 by gathering 51 participants from the Ratchaburi, Nakorn Pathom, and Pathuthani province which are the main vegetable production areas in central region in Thailand. These 51 participants were composed of 15 vegetable farmers, 10 traders, 5 trading companies, 12 district officers, 6 province officers, and 3 representatives from national service provider. Analysis was made and reported through explanation and illustration.

\section{RESULTS AND DISCUSSIONS}

\section{The role of marketing information}

The role of marketing information for vegetable was designed to: (1) provide local producers and traders information on wholesale and retail prices of vegetable on a regular basis; (2) provide producers information on annual price trends of farm commodities for better production scheduling; (3) assist producers in deciding where, when, how much, to whom and in what price to sell their current produce in order to lessen marketing risk; (4) improve the bargaining position of producers; and (5) help institutional buyer keep updated prices as bases for their procurements.

\section{Fresh vegetable marketing channel}

The 2 main marketing channels for vegetable are as follows:

(1) Marketing channel involving a central market Most vegetables are delivered through this channel.

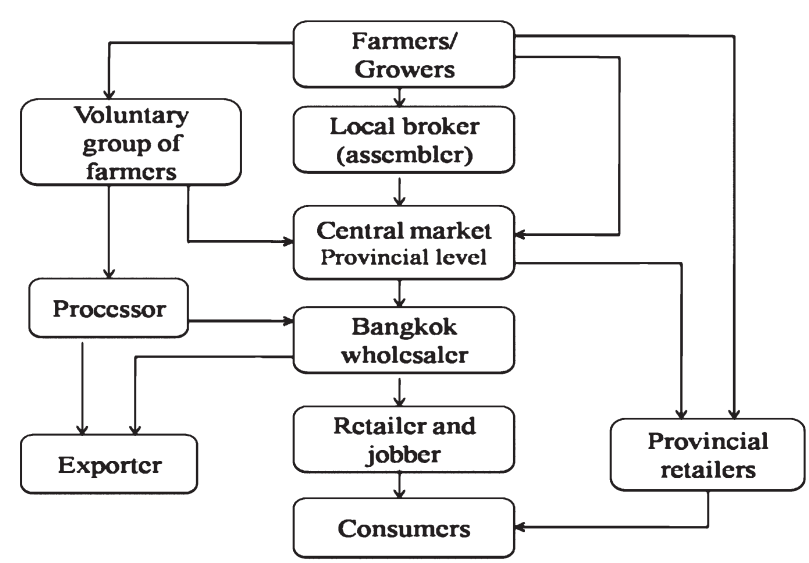

Fig. 1. Vegetable marketing channel involving central market.
Farmers combine their produce and sell it in a central market at provincial level, or sell it to village assemblers, who take it to the central market. From the central market, the Bangkok or provincial wholesalers purchase the produce and then sell it to retailers. Some produce goes for export, through a processor or a Bangkok wholesaler. (Fig. 1)

\section{(2) Marketing channel not involving a central} market

Farmers sell their vegetables, either to village assemblers, provincial wholesalers, processors, or directly to exporters. Some farmers haul their produce to a trader or processor. Some farmers enter into contracts to supply vegetable exclusively to particular processor or exporter. The village broker or assemblers sell their produce to a wholesaler or processor. The wholesaler in turn sells the produce to retailers, processors and exporter. (Fig. 2)

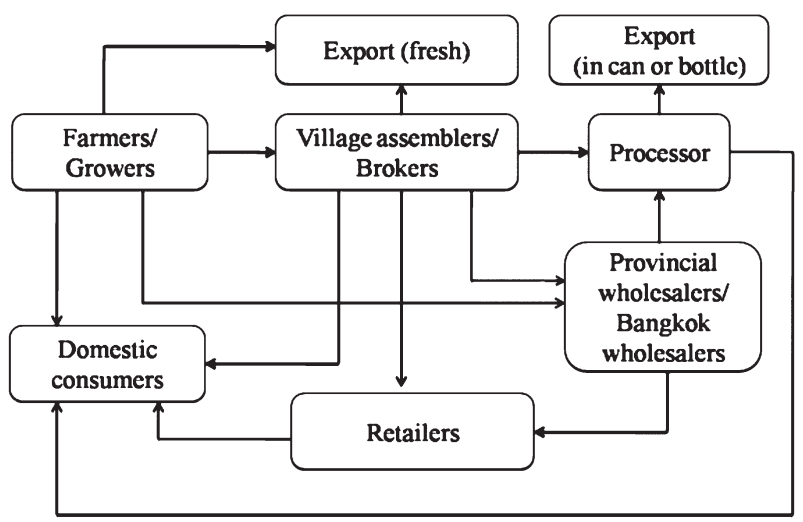

Fig. 2. Vegetable marketing not involvin s g central market

\section{Provision and dissemination of market informa- tion for fresh vegetable}

(1) Provision of marketing information

Vegetable marketing information is provided by DIT and OAE which have jointly set up information. OAE collects weekly and monthly data which on are farm gate price and average market price and distributes them to market members. Moreover, OAE analyzes statistics data and forecasts market trend through the annual report. On the other hand, DIT collects data from wholesale and retail markets as well as from 16 central markets in provincial level which encouraged by DIT. They will then provide price information to producers, traders, and consumers as a major service item. Reports are issued on a daily, weekly, monthly, and annual basis. The marketing information flash through the communication techniques by extension worker from AEO, and main public media releases such as radio, television, and newspaper, as well as through government printed reports. However, extension workers have traditionally played a major role in providing information by advising farmers through their extension services on farm management options, in case that marketing information is provided in a small proportion. (Fig. 3) 


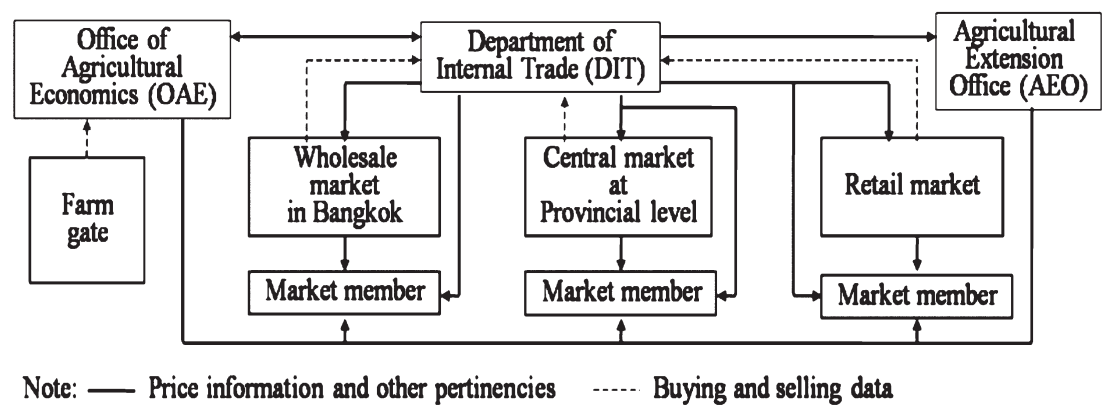

Fig. 3. Provision of marketing information.

(2) The dissemination of vegetable marketing information

- Distribution by mass media

Major information media holding of farmers are the television, government officials, radio, and print media which is $100 \%, 67.7 \%, 60.3 \%$, and $54.0 \%$ of the media exposure respectively. The television is the main channel for sending the information to the farmers. Although, the most popular television networks in the country which broadcast 24 hours a day have allocated less than 15 minutes air-time a day to the agricultural program. Out of the 15 minutes allocated to agricultural program, only 1-2 minutes are devoted to agricultural marketing.

For radio program, it has no specific program layout in agricultural marketing. Majority of the information are about agricultural production and a little on price information. It will provide more marketing information in case problem situation arose.

Print media through daily newspapers often provide marketing information. It comprises day price information. The daily newspaper of Thairat and Dailynews exemplify this kind of information media.

For the internet, which is a kind of marketing information media, it contains daily, weekly, monthly marketing information. Although computer equipment are very useful for the collection and processing of marketing information, they seem to play a minor role in the dissemination of information to farmers. Very few farmers use personal computer to access marketing information services and carry out on-line searching for the information they need.

\section{- Personal media used by farmers}

The farmers used this information as basis for understanding the market environment so they would know what decision to make. In practice, however, farmers cannot really benefit from the existing information owning to some reasons.

For one thing, the price of vegetable, in particular, fluctuates daily and even hourly. The price in the morning would be different from that in the afternoon, or the average price today would be different from that of tomorrow. It is extremely difficult to make accurate price forecast since accuracy increases as time frame included in the forecasting becomes longer. Due to this, farmers have not been able to make correct future production plan, either in terms of planning time, crop combination or plant acreage.

The market power, which is the other prominent reason, is predominated by traders. All commodities, without exception, are under such inefficient marketing system. In consequence, any increases in price cannot be fully captured by farmers.

However, for farmers to argue for better prices, they must either have sold produce in the assembly market or must have a very good idea of what prices the traders are offering. Local extension services can perhaps assist farmers by monitoring assembly market prices on a daily basis and posting the prices on a notice board at the entrance to the assembly market. Although such activities might involve too much work for an individual extension officer, a regional or provincial headquarters of the extension service, which is based in the same town as the assembly market, could consider assisting in this way.

\section{The constraint of marketing information}

The process of communication development with the new media tends to increase people's desires and their accessibility power to the marketing information faster than the others. However, it is found that the constraint of vegetable marketing information is the opportunity to access the main sources of information. The traders are able to access the information from international market, Bangkok wholesale markets and intertrading firms at once because of individual communication networks linkage which means that they can compare the vegetable price in each market. For the farmers, they are able to reach the marketing information only in the local markets which are the lowest end at farm price levels. They are in the position to accept the set price that is marked by middleman in local market. Farmers have no opportunity for comparing the price unlike the traders who are able to negotiate the price.

The other constraint is the speed in accessing the marketing information. Farmers have limitation in accessing the internet network where daily vegetable marketing information is available. They are still relying on television and radio which are inadequate in both frequency and agricultural marketing news up-dating. Traders at all levels are able to reach the markets at once because of communication networks linkage through the internet. 
The equality of access to information which is referred in Eldon et al., as it affects short term and/or individual bargaining power, may have consequences for the long term pattern of wealth and income distribution and for long term political development.

\section{Sharing experiences in participatory approach among stakeholder}

The steps of Participatory approach through workshops are as follows:

Step 1: Select the study area which are the main of vegetable production area and have central market in the area for sharing with representative from the market. Ratchaburi, Nakorn Pathom, and Pathuthani province were selected as study area.

Step 2: Consider the stakeholders who participate in the action research for finding the needs and the ways to develop marketing information. In this workshop, vegetable farmers, traders, trading companies, district officers, province officers, and representatives from national service provider were the participants.

Step 3: Make arrangements for the equipment to be use in the workshop and notify participants who will attend on a particular day.

Step 4: Undertake the workshop. Typical formats for the survey such as the problem, question and answer will be applied. Discuss the various options with the participants and try to reach outcome of agreement for further development. The workshop was carried out through open discussion for 4 days on 3 sessions in each day.

On the first day, an overviewed of the project concept and workshop process as well as finding problem situation on vegetable production and marketing were discussed. The second day and third day were the continuation of finding the marketing information needs and expected benefits from system. For the fourth day, conclusion and action plan were set for developing marketing information system. (Fig. 4)

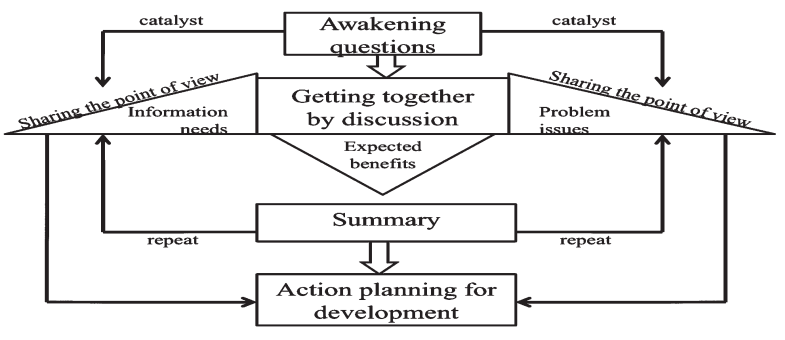

Fig. 5. Workshop process.

The participants were divided in 6 groups according to their role which consist of vegetable farmers, traders, trading companies, district officers, province officers, and national level information providers. Group discussion was based on 3 key questions:

(1) What are the problem issues in vegetable marketing?

(2) What are the market information needs for vegetable production and marketing?

(3) What are the benefits to expect from improved market information? (Fig. 5)

\section{Problem issues, market information needs, and expected benefits}

(1) The workshop outcome on problem issues, market information needs, and expected benefits from improving marketing information in vegetable market were summarized in the following table 1:

(2) Participants agreed on a set of recommendations for developing Market Information System (MIS). They could be summarized as:

(1) National level information providers should develop a national level task force to develop a framework and working mechanisms for national level MIS.

(2) Government should establish enabling policies at

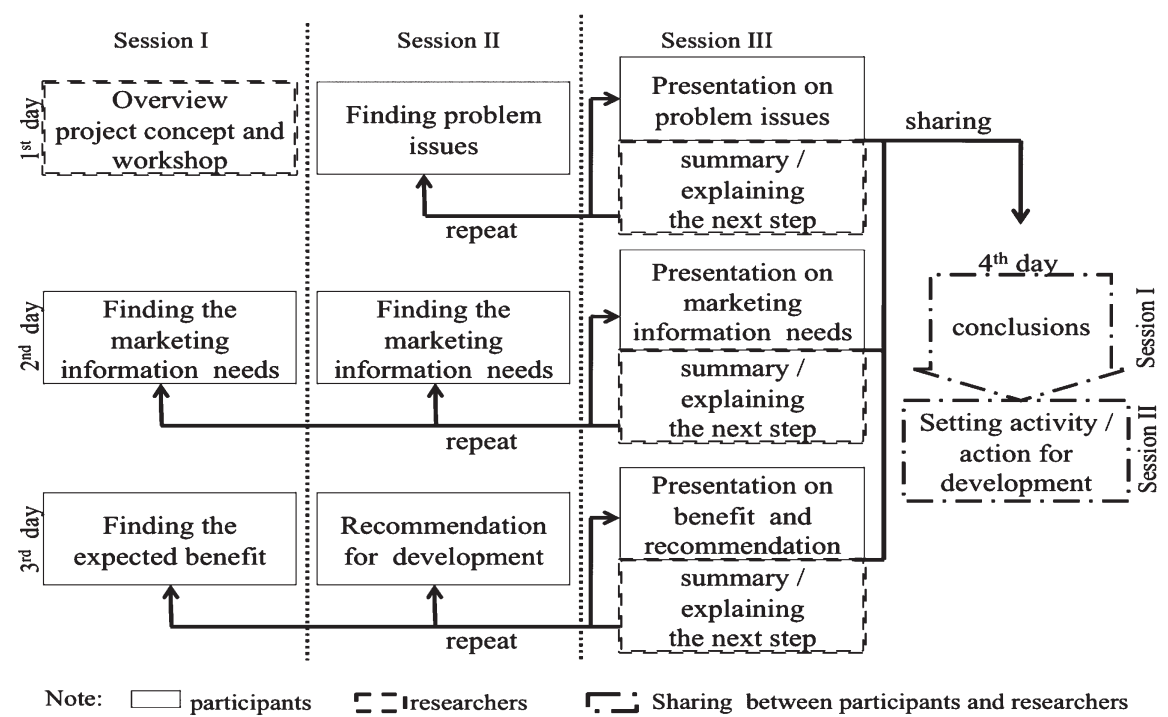

Fig. 4. Workshop undertaking. 
Table 1. Problem issues, market information needs, and expected benefits

\begin{tabular}{|c|c|c|c|}
\hline & Problem issues & Information needs & Expected benefits \\
\hline 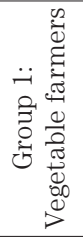 & $\begin{array}{l}\text { - Lack of market information } \\
\text { - Poor production and harvesting } \\
\text { techniques } \\
\text { - Lack of price guarantees } \\
\text { - Poor infrastructure }\end{array}$ & $\begin{array}{l}\text { - Market information } \\
\text { - More efficient production and } \\
\text { harvesting techniques } \\
\text { - More efficient and supportive } \\
\text { regulations along the marketing chain }\end{array}$ & $\begin{array}{l}\text { - Better decision making ability on } \\
\text { investments } \\
\text { - More bargaining power for village } \\
\text { producers } \\
\text { - Stable markets for agricultural } \\
\text { products }\end{array}$ \\
\hline 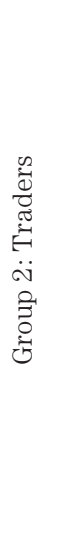 & $\begin{array}{l}\text { - Lack of data, networking, } \\
\text { dissemination of market information } \\
\text { - Government lack budgets to work } \\
\text { on marketing information system } \\
\text { - Policies and regulations are not } \\
\text { geared to promote market production } \\
\text { - Infrastructures are weak } \\
\text { - Quota systems do not provide enough } \\
\text { protection to investors against } \\
\text { unregistered traders } \\
\text { - Few models and are in place to } \\
\text { promote rural microenterprises } \\
\text { - Very few examples of product } \\
\text { quality improvement are ready for } \\
\text { up-scaling }\end{array}$ & $\begin{array}{l}\text { - Market demand, prices, quality } \\
\text { requirements, seasonality } \\
\text { - Information on trade regulations } \\
\text { and their logic } \\
\text { - Models for improving market } \\
\text { infrastructures } \\
\text { - Information and training capacity } \\
\text { for more efficient production } \\
\text { methods } \\
\text { - Economic methods to calculate } \\
\text { profitability }\end{array}$ & $\begin{array}{l}\text { - Increased production according to } \\
\text { market demand } \\
\text { - Better production planning, } \\
\text { - Reduce illegal trading } \\
\text { - More choices in production for } \\
\text { markets } \\
\text { - Correct price structures, } \\
\text { - More funds raised for investment } \\
\text { - Better networking and information } \\
\text { exchange } \\
\text { - Human resources developed } \\
\text { - Databases for market information } \\
\text { are set up } \\
\text { - Small business development } \\
\text { supported }\end{array}$ \\
\hline 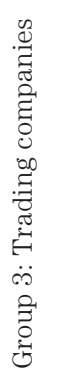 & $\begin{array}{l}\text { - Problem of unregistered small traders } \\
\text { - Systems for taxation and } \\
\text { implementation of regulations, } \\
\text { - Price setting } \\
\text { - Low productivity } \\
\text { - Low quality of products } \\
\text { - Limited validity of contracts } \\
\text { - Lack of basic infrastructures } \\
\text { - Lack of processing } \\
\text { - Village producers are not market- } \\
\text { oriented }\end{array}$ & $\begin{array}{l}\text { - Information on markets (quantity and } \\
\text { quality) according to season and } \\
\text { production area } \\
\text { - Quality demands } \\
\text { - market regulations and policies } \\
\text { - Meetings and workshops at province } \\
\text { level }\end{array}$ & $\begin{array}{l}\text { - Stakeholders will be better informed } \\
\text { on market opportunities and } \\
\text { production techniques }\end{array}$ \\
\hline 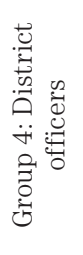 & $\begin{array}{l}\text { - District officers lack capacity to } \\
\text { improve market access } \\
\text { - Lack of data on prices, and technical } \\
\text { skills } \\
\text { - Nobody takes responsibility for MIS }\end{array}$ & $\begin{array}{l}\text { - Prices } \\
\text { - Supply } \\
\text { - Demand } \\
\text { - Seasonality } \\
\text { - Policies and Regulations }\end{array}$ & $\begin{array}{l}\text { - More efficient marketing chains } \\
\text { - Effective policies from the } \\
\text { Government } \\
\text { - Reduced costs of production } \\
\text { - More capacity to understand markets } \\
\text { - Better opportunities for exchanging } \\
\text { experiences }\end{array}$ \\
\hline 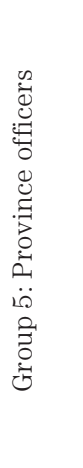 & $\begin{array}{l}\text { - Lack of data on product quality and } \\
\text { price } \\
\text { - Method of data collection } \\
\text { - Lack of coordination between projects } \\
\text { and offices } \\
\text { - Lack of credit facilities } \\
\text { - Problem with middlemen, } \\
\text { - Unstable markets } \\
\text { - Lack of market and transport } \\
\text { infrastructure } \\
\text { - Lack of supportive regulations } \\
\text { - Lack of technology for product } \\
\text { processing }\end{array}$ & $\begin{array}{l}\text { - Prices along the chain } \\
\text { - List of buyers } \\
\text { - Product quality information } \\
\text { - Seasonal changes in markets } \\
\text { - Size and location of sources of raw } \\
\text { materials }\end{array}$ & $\begin{array}{l}\text { - More correct planning of production } \\
\text { - Better focus in extension for } \\
\text { marketing of products } \\
\text { - Ensured markets } \\
\text { - More confidence among producers } \\
\text { to produce for markets } \\
\text { - More equal distribution of benefits } \\
\text { from agricultural trade } \\
\text { - Better linking of farmers to markets }\end{array}$ \\
\hline 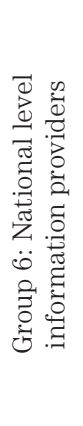 & $\begin{array}{l}\text { - Lack of detailed data } \\
\text { - Lack of regulations } \\
\text { - No effective provision of market } \\
\text { information } \\
\text { - Lack of human resources to collect } \\
\text { and disseminate market information } \\
\text { - No assessment or review are made } \\
\text { of the situation } \\
\text { - No mechanism for information } \\
\text { exchanging market information }\end{array}$ & $\begin{array}{l}\text { - Data on production } \\
\text { - Costs and prices } \\
\text { - Improved technology for production } \\
\text { and harvesting } \\
\text { - Details of production } \\
\text { - Supportive and efficient policies and } \\
\text { regulations } \\
\text { - Up-to-date information on demand } \\
\text { from buyers } \\
\text { - Statistics of export and import data } \\
\text { - Information on export support } \\
\text { measures }\end{array}$ & $\begin{array}{l}\text { - Improved market information to users } \\
\text { - Easier access to market information } \\
\text { - Improved coordination between } \\
\text { Government and Private Sector } \\
\text { - Transparency in policies } \\
\text { andregulations at all levels }\end{array}$ \\
\hline
\end{tabular}


all levels and enforce respect for contract arrangements.

(3) Province and District levels should take the lead in developing local MIS.

(4) Project researchers should support provincial and district MIS initiatives with capacity building and funding, and ensure good coordination with the private sector.

(5) Traders and Companies should form an association of companies to coordinate with Government and other actors.

\section{CONCLUSION}

Farmers, local assemblers, wholesalers, retailers, and consumers, primarily, want timely information that will help them make decisions on buying and selling. As a role, traders have much better information than farmers and are thereby in a stronger negotiating position. Farmers frequently arrive at market without a firm idea of the price. Providing farmers with type of information in a timely manner can significantly help them in production planning and increase their bargaining position, and their ability to make good marketing decisions.

A farmer who knows the market price and who has an approximate idea of the marketing of the trader is in a much better position to negotiate than the one who has no idea of either. Farmer must seek out and compare the information available for different outlets if they are to sell to the best purchaser.

Extension workers should help farmers by indicating the likely margin that the trader requires and by updating this information whenever possible.

Even though, at present the communication development has progressed to a high level in terms of technology and mass media, the distribution ratio on marketing information is still a small proportion. Therefore, in order to develop marketing information system for vegetable and to settle marketing information in where and how, the simplest means should be investigating farmers' requirement, media accessibility, and ability to use the information.

The participants in the marketing information workshop learned a lot about marketing information and activities. They also learned about marketing information system and ways to set up and develop the system. However, any method utilized in assessing marketing systems needs to be easing applied and be well understood by rural communities. Usually, answering direct question on marketing is not difficult for farmers and they are able to express opinions on the problem they encounter and their needs. Such discussions with concerned stakeholders are very useful as a means of obtaining a rapid and representative assessment of local marketing information condition and problems.

The major problem issues mentioned were low income because of low productivity and dependence on markets, lack of mechanism to access marketing information, and lack of models for successful rural market development.

The major marketing information needs of stakeholders consist of:

- Information on markets according to quantity and quality

- Prices along the chain

- List of buyers

- Market regulations and policies

- Information on efficient production, storage, and processing methods

- Meetings and workshops at all level of stakeholders

The expected benefits from improving the MIS were reduced rural poverty, accelerated economic growth, improved governance, and developed human resource.

These will bring about a deep understanding and relationship of the dissemination pathway of marketing information to the vegetable farmers with emphasis on analysis performance of the market agents from farmers, wholesalers, exporters, importers, retailers, and consumers. Thus, a national MIS taskforce should be set up to collect and disseminate market information throughout the country. It is important to establish clearly which organizations will be responsible for building an MIS, who can contribute to data collection, processing and dissemination and how this institution could co-operate smoothly in network and linkage by building participation from stakeholders in the market.

\section{REFERENCES}

Andrew W. Shepherd. 1997. Market Information Services-Theory and Practice, Food and Agriculture Organization of United Nations, pp. 6-7

Eldon D. Smith, Nguen Srisuruksa and Perry Phillipp. 1971. Local Market Information Service in the Strategy of Agricultural Development. Southern Journal of Agricultural Economics, p. 61

Philip Townsley. 1996. Rapid rural appraisal, participatory rural appraisal and aquaculture. FAO Fisheries technical Paper 358, Food and Agriculture Organization of the United Nations, Rome 